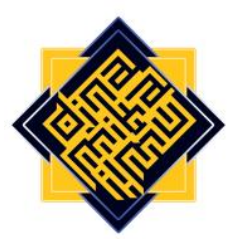

\title{
Call for the Return to the Qualities of the Traditional Muslim Mind
}

\author{
Mohd Abbas Abdul Razak \\ Asst. Prof. at the Department of Fundamental \& Inter-Disciplinary Studies, IIUM, Malaysia \\ e-mail:maarji@iium.edu.my \\ Sayed Sikandar Shah Hanif \\ Professor at the Department of Fiqh \& Usul Fiqh, IIUM, Malaysia \\ e-mail: sayedsikandar@iium.edu.my \\ Muhammad Abdurrahman \\ Assoc. Prof. at Fakultas Tarbiyah dan Keguruan UIN Ar-Raniry Banda Aceh, Indonesia \\ e-mail:muhammad.ar@ar-raniry.ac.id
}

\section{Abstract}

The world we live today has undergone a dramatic change in values, science and technology. In a world so divided with contending ideologies and worldviews, humanity as a whole has derailed from its philosophy of co-existence, tolerance and mutual respect for one another's faith and culture. The war that should have ended with the formation of the United Nations is still raging in many parts of the world. News and business are controlled by some powerful conglomerates. The gap between the haves and have not's still persists. In the wake of the present global condition, Muslims and their religion are targeted and falsely labeled as a global threat. This apparent situation of the world calls for the new generation of Muslims to think and re-evaluate on how to respond to the challenges and criticisms that come from others. Moreover, they have to carve out new ways to co-exist with others and on how to preserve their religion and cultural heritage of the past. Through this paper, the researchers intend to investigate the style of thinking of the great Muslim scholars during the heydays of the Islamic civilization and propose the importance of reviving such an orientation of thinking in the contemporary Muslim world. As a qualitative study, the researchers intend to present some historical evidence on the remarkable 
Mohd Abbas Abdul Razak et al.

achievement of the Muslim scholars of the bygone centuries. The textual and document analysis methods will be employed in interpreting the relevant data of the study. Pertinent data related to the research will be retrieved from print and electronic media.

Keywords: Call, Muslim Mind, Qualities, Return, Traditional

\section{A. Introduction}

Muslims who once built great empires and civilization have now lost their vitality and meshed in their own dilemmas of how to maintain good governance, develop their countries in terms of eradicating poverty, diversifying their economy, maintaining peace and stability, in dealing with modern science and technology, in co-existing with others, etc. Though in the past, many great minds from the intelligentsia community have provided the panacea through their great research works, but the reality today proves that very little progress has been made over the centuries. In view of the present tumultuous condition of the Muslim nations all over the world and for a reason that obscure names were given to them by others, particularly the West, this research is geared towards finding some of the root causes as to why Muslims have never moved from the problem of the past (Bakar, 1991). Based on the premise that many of the issues in the Muslim world is related to the ways of how they think and respond, via this study, the researchers would like to propose an amicable solution to remedy this pathetic condition of the Muslim Ummah. Furthermore, from the outset of this investigation, the researchers would like to drive home the idea that suggestions put forward by the team are neither intended to further deteriorate the condition in the Muslim World nor to cause a rift between the Muslims and others, particularly those in the West. On the contrary, this modest effort put forward by the team should be seen as no more than an addition to the existing corpus on the research in the area of Islamic civilization (Bakar, 2008).

The Muslim mind that contributed immensely to science, technology, philosophy, and spirituality during the peak of the Islamic civilization (750-1258), has somehow lost the 'Midas Touch' during the era of modernity and now globalization. As a result of colonization, problems of post-colonization, and internal turmoil in the Muslim world, Muslims were not able to contribute significantly to the development of science and technology in the contemporary world. At the moment, they have become the largest consumer society in the world. In addition, Muslim countries, ever since the fall of the Islamic civilization up until now are somehow experiencing political instability, lack of good governance, leadership crisis, war, terror attacks, to name a few (Al-Attas, 1978; Hassan, 2011). In realizing the fact that the Muslim world is saddled with enormous problems and lagging behind others, particularly the West, this research is geared towards exploring the greatness of the Muslim mind of the past and how such a mind can be resurrected and developed in Muslim countries. As a qualitative study, the researchers will dwell upon the greatness of the past Muslim scholars, what is meant by the traditional mind, the present condition of the 
Muslims, how the traditional mind can be developed and what is the way forward left for the Muslims with this new resurrected mindset (Amer, 2002; AbuSulayman, 1993).

\section{B. Heydays of the Islamic Civilization}

Many historians say that the golden era of the Muslims happened during the peak of their civilization (750-1258). Others say it lasted for a much longer period of time. Regardless of the disagreement of the actual time frame of the golden era, it was during that time the Muslim world witnessed the budding of many polymath scholars. These scholars were able to master many disciplines of knowledge. Though they were deep in their religious sciences, they were equally good as well in the field of natural and human sciences; like botany, pharmacology, surgery, astronomy, mathematics, algebra, geography, etc. (Nasr, 1994).

The main centers of knowledge, scientific research, philosophical and religious debates were taking place in Baghdad (Iraq), Cordova (Spain), Damascus (Syria), and Cairo (Egypt). Compared to the last two, the epicenter of intellectual activities were mainly taking place in Baghdad and Cordova. Research works in the areas of human and natural sciences conducted in these centers, particularly in Darul Hikmah (Iraq) attracted many Western scholars to these centers to study through the medium of Arabic. As such, during that time, Arabic became the lingua franca for science and philosophy. Benefitting from the research works done by eminent Muslim scholars, Renaissance scholars took back the ideas to Europe. Great books written by Ibn Sina (980-1037), Al- Farabi (897-950), Al-Ghazali (10581111), Al-Biruni (973-1050), Ibn Rushd (1126-1198), Ibn Khaldun (1332-1406) and others were translated into many European languages. It has been said that it was Ibn Rushd, who was able to capture well on Aristotle's rational philosophy, introduced it to the West (Fakhry, 1983). Even Saint Thomas Aquinas (1225-1274) had referred to Ibn Rushd's work as a way to understand Aristotle. Likewise, Aquinas has also referred to Al-Ghazali's work on moral development before he could come up with his own teaching in that area. For the great service Ibn Rushd did for the West in interpreting Aristotle's work, people in the West till today acknowledge his fabulous contribution and feel more indebted to him than AlGhazali. In contrast, the latter is more famous in the Muslim World, for his great compendium of literature in the area of Islamic sciences, particularly in matters related to spirituality (Sheikh, 1974). Except for a few, many Europeans failed to acknowledge the fact that the ideas provided by the Muslim scholars acted as an impetus for the European Renaissance movement. In other words, ideas from the Muslim scholars acted as a 'spark' that set the Western scholars ablaze in their quest for more knowledge and enlightenment. The Europeans did not stop after getting knowledge from the Muslims, but they did further research and development, applying their knowledge to other areas of research (Nasr, 1994).

Interesting to note that during the heydays of the Islamic civilization, a fair deal of Christian, Jewish, and Zoroastrian experts were employed as teachers and translators of ancient manuscripts at the Islamic centers of intellectual activities. Notably, the most famous center for research, learning, and translation work was happening at Bayt al-Hikmah in Baghdad. It was a normal scene at Bayt al-Hikmah to witness people communicating in 
Mohd Abbas Abdul Razak et al.

Arabic, Farsi, Aramaic, Hebrew, Syriac, Greek and Latin. The mindset of the Muslims at that time was, religion is something that comes from God and there should be no compromise on its fundamental teachings, while civilization is a human product (Fakhry, 1983). As such, it is very natural for one civilization to learn from the other. Truly, the civilization that comes later will learn all that is positive from the bygone civilizations. An avid reader of history, without a doubt will agree that the Islamic civilization as a dynamic force had learned and borrowed ideas from earlier civilizations; like the Greek, Persian and Indian. This fact of borrowing ideas among different civilizations has also been highlighted by lqbal (1877-1938), the great Muslim poet-philosopher. Like others, he too highlighted that there was a time in history, European thought received inspiration from the world of Islam. Many centuries later, after freeing themselves from the clutches of colonialism, the Muslim world in return, started to imitate some of the dynamism in the areas of science and technology found in the West. To lqbal, this act of borrowing ideas from the West by the Muslims was more or less an act of taking back the lost heritage of the Muslims of the past (lqbal,1996).

\section{Research Methodology}

In consonance with the nature of the study, the researchers employed the qualitative method in collecting the relevant data. As such, this study purely used the library research that falls under the realm of qualitative research. Information collected for the study was analyzed from two dimensions/domains: from the philosophical as well as from the historical viewpoints. Therefore, the data presented in the study reflected the philosophical and historical developments, particularly in the past and present political, social, and intellectual milieus in the Muslim world. According to Sharma (1988), human conduct can be analyzed by two means; one is the direct behavioral way and the other is the indirect behavior. To him, the content-analysis method is the indirect measure or procedure to evaluate human behavior. In his explanation on how content analysis can be used, Sharma, like Nachimias \& Nachimias (1982) and Busha \& Harter (1980) stated that it could be employed to deduce characteristics of communications. In further particularizing the forms of communication that can be analyzed using the content analysis method, these experts have suggested that newspapers articles, letters, minutes of meetings, autobiographies, interviews recorded in tapes or films, personal diaries, books, speeches, TV interviews, diplomatic messages, etc. can be used.

Supplementary to the content analysis method, the researchers used the historical method in conducting the investigation on the topic. Through the use of the historical method, the researchers surveyed the historical events that happened in the Muslim world. Upon studying the historical facts, the researchers reinterpreted them afresh in the light of the information gathered for the purpose of this study. According to Verma \& Verma (1989) and Denzin \& Lincoln (2008), in conducting research using the historical method, one can use books, magazines, accessible documents, papers, literature, cultural and analytical history material, memories, personal letters, and accounts, authentic observers, witness, etc. In light of the suggested source materials, the researchers made use of whatever available information, be it primary or secondary, related to the subject matter of the study. 
As a qualitative study, the researchers relied mainly on literature, dissertations, articles, seminar papers, documented lectures, and other information available in the libraries and that could be retrieved via the electronic media, mainly the internet.

\section{Findings and Discussion}

\section{Present Condition of the Muslim World}

Muslims who created great empires and a dynamic civilization in the bygone centuries are now faced with an enormous amount of problems from within and the outside their countries. Muslim World as once a civilizational force that produced intelligentsia in many disciplines of knowledge, after the European colonization and post-colonial period, started dwindling in its valor and spirit as the custodian of knowledge. Colonization had somehow dented the Muslims of their ego and created a sort of inferiority complex. As a result of this psychological state of mind, the Muslims started to lag behind others in terms of science, technology, and nation-building (Al-Roubaie, 2002).

Colonization had also divided the Muslims in some ways, giving rise to disunity among them. As a divided Ummah, Muslim countries lost the strength to speak as a single nation. This situation has given an advantage for others to set them against one another. Different political aspirations had let them into war and sectarian violence that are still prevalent in many Muslim countries. Countries like Iraq, Iran, Syria, Libya, Afghanistan, Saudi Arabia, and Yemen have experienced war. Some of these countries are still waging war within the country and at the frontiers with neighboring countries. To a certain extent, external forces should also be blamed for taking advantage of the situation and used their mass media to create a war in Muslim countries. The motive for creating political instability in the Middle East and elsewhere in the Muslim world is none other than to usurp the wealth that comes through their natural resources like oil and gas. The absence of clarity of the mind and the failure to understand the deceitful strategy of the external forces caused the Muslim nations to go against one another. Many wars were fought and still going on in Muslim lands, causing death to scores of their civilians, damage to their infrastructure, and triggering environmental degradation on land, sea, and air (Abdul Karim,1991).

The war in the Middle East, Africa, and other regions of the Muslim world has caused many to lose faith in their governments and move on to a more secured region of the world. As a result of the chaotic situation in Muslim lands, pockets of migrant population who had braved the mountains, deserts, and rough seas without bothering the heat and the cold to crossover to foreign lands. Their survival instinct made them perform the impossible to sustain their lives and the lives of their dear ones. In recent years, there was an influx of refugees from the Middle East to Europe and America. It has been reported that over the years some 25 million Muslims who are refugees, migrants, or asylum seekers from different parts of the Muslim World have taken residence in Europe. Their presence there is not always welcomed one by all. A fraction of the local citizens complains that the arrival of the Muslims has increased the burden for their government to facilitate these foreign visitors who come with an alien culture that is different from the one in Europe. These Muslims had to leave behind their homes and possessions in search of a safe haven to start a new life in 
Mohd Abbas Abdul Razak et al.

an environment where peace and security prevail. Despite their expectation, in some parts of Europe, these Muslims have to face discrimination, racism, marginalization and at times anti-Islamic sentiments, now popularly known as Islamophobia from the people of the land. Though this scenario is pathetic to watch and hear, the fact will remain the same as the blame should go back to their government and political leaders of their country of origin in the Middle East (Khader, 2015).

Leadership crisis is another issue that has been plaguing for very long in most Muslim countries. The greed for power and control of the wealth of the nation has caused rivalry among political leaders. Obsession for power has created an unhealthy political atmosphere in many Muslim countries, surprisingly now even in Malaysia and Turkey. As if it is a new norm that leaders in Muslim countries have been discrediting and attacking one another's political philosophy and the agenda they have crafted for the nation. This sort of political climate is not good as it gives the opportunity for others to take advantage to tarnish the image of Islam and the Muslims. Political leaders have gone beyond all ethical principles in grabbing power. Smear campaign, character assassination, conspiracy, lies; unfulfilled manifestos, etc. have become the new norms in the political arena even though they are Muslims. Worse, in some countries, we often hear terror attacks, suicide-booming, assassination attempts, etc. All this is done just to win an election or grab power by a coup d'état. When too much of politicking is going on in a Muslim country, the possibility of neglecting the welfare of the people will be very high. Due to too much of politicking, the economy, foreign investment, education, health, poverty, etc. will be left unattended. At times, many of these problems can cause the nation backwardness and will never be able to catch up with the rest of the world (Hiro, 1989; Hosein, 2011).

When there is a war happening between two Muslim countries, much of the national budget will be spent for military needs; particularly for the purchase of armaments to strengthen the country's military prowess. So, it will be a wise thing for Muslim nations under conflicts to negotiate peace talks rather than to go into war at one another. Leaders in such countries should be wise enough to think about the safety of the people and channel the money spent on buying weapons and missiles to the nation's educational and health care needs. In fear of war and political instability, professional and experts in some Muslim countries migrate to Europe and other parts of the world in search of better prospects for their families; better living standard, good education for their children, better income for themselves, the availability of research centres with up to date laboratories and facilities. The loss of professionals from such Muslim countries in the form of brain drain will most likely make the country stay backward and will never be able to compete with the rest of the world (Abdul Razak, 2015).

The researchers feel that all the above stated problems in the Muslim world are related to the way in which the leaders and masses think. If they happened to think in a broader perspective by integrating spirituality, science, and philosophy, they will be able to function in a more dynamic way. Moreover, with this mode of thinking, they can come out from their backwardness and turn their nation into a progressive and prosperous one, eradicating poverty, illiteracy, political chaos, war, etc. 


\section{The Traditional Muslim Mind}

The traditional mind is one that is beyond conservatism and backwardness. It is a brilliant mind that is scientific, philosophical, spiritual, creative, critical, and analytical at the same time. Though it is a mind deeply engrossed in the world, yet it is anchored in the thought of God and the readiness to serve Him and humanity. More to add, it is a mind that is bursting with dynamism, new and progressive ideas. Muslim scholars who possessed such a mindset were willing to learn all that will be beneficial not only for the survival of the Muslims but also for humanity as a whole. As such, they were willing to blend science, philosophy, and spirituality in the hope to bring benefit to humanity. For them, using the mind in the most productive manner contemplating on God, the human creation, and the natural world; flora and fauna in a way, was a form of Ibadah (worship). As the Khalifah of Allah (vicegerent of God) they need to display the two emphases of the Qur'an; Zikr and Fikr. The Zikr of the Qur'an calls for man to lead a God-centered life that requires him to observe the dos and don'ts mentioned in the Holy Scripture. Besides that, the Zikr also refers to the remembrance of God, prayer, meditation, contemplation of the universe, deep thinking, fasting, alms giving and all other virtuous deeds mentioned in the Qur'an. While Fikr refers to science, technology, and also knowledge with regard to the natural and social sciences. In Islam, Muslims are encouraged to strike a balance between the two (Zikr and Fikr). According to scholars like Iqbal (1877-1938), Sheikh Muhammad Abduh (1849-1905) and others, the Muslim Ummah (nation) can be great if it has mastered both of the emphases mentioned in the Qur'an. Leaving either one of the two can cause an individual or the nation of Islam to either suffer from moral degradation or poor economic growth. On the other hand, too much emphasis on spirituality at the expense of neglecting Fikr can cause the Muslim Ummah to be dependent on others on worldly matters. This is not an ideal situation for the Ummah. Short term dependency on others for science, technology, and expertise should be a thing acceptable in all communities of the world. But if such a thing prevails over a long period of time, it can drain the wealth of the Ummah in terms of buying technology and armaments. Moreover, whatever given to us by others might not be the latest technology. In understanding the politics involved in buying armaments and technology, the ideal thing to do will be to develop our own technology and use it for a good cause (Abdul Razak, 2016).

\section{The Concept of the Mind from different Perspectives}

Although radical behaviourists like JB Watson (1878-1958) and BF Skinner (1904-1990) negated the existence of the human mind they acknowledged the role and operation of the human brain as an information processing unit in human beings. For them, the child is a mere 'tabula rasa' or a clean slate at birth. Besides that, they also did not believe in concepts like innate or latent knowledge with regard to education. For them, a child learns everything presented to it from the external world through the process of; stimulus, response and reinforcement. Apart from that, they believed that human personality, motivation, creativity, etc. are all learned behaviours (Watson, 1928; 1970). Diametrically opposite to the 
Mohd Abbas Abdul Razak et al.

behaviourists, Sigmund Freud (1856-1939) believed and emphasized that the inner dynamics of man is more dominant than his environment. Freud used the term psyche to explain the mind. Initially, he presented the topographical model of the mind by explaining its three components; the unconscious, sub-conscious and conscious. Later, he came up with his structural model which is made up of three waring entities: the Id, Ego and Superego. According to him, all the three components will be at war at each other in taking control of the mind (Freud, 1950; 1962; 1989). Looking man in a sympathetic manner, humanistic psychology explained man and the concept of the mind in a different way compared to the Freudian and behaviourist theories. Maslow (1908-1970) and Carl Rogers (1902-1987) explained the mind in relation to the whole individual by referring it to concepts like, the self, free will, self-efficacy, and self-actualization (Maslow, 1968).

In Islamic psychology, the mind ('aql), heart (qalb), self (nafs) and the spirit/soul (ruh) are one and the same thing. All these terms are used interchangeably in the Qur'an to explain the human psyche and the spiritual dimension of man. The first three come to exist after the infusion of the spirit/soul (ruh) to the fetus in the mother's womb. As a child is born and growing into maturity, all the other psychic components start to play their designated role in the human body (Al-Attas, 1990; 1991). The mind is the soul in fact. The soul uses the mind in relating itself to the external world and in learning from the environment. The brain is the organ that is being used by the mind for processing information, storage, and retrieval. In other words, the brain is the organ, while the mind is its working mechanism. When an individual observes or come in contact with an object the information is transmitted by the sense perceptions to the brain and later interpreted by the mind. The mind is not only fed with information by the eyes, but also from the taste buds, sense of earing and touch. Since the mind occupies an important position as one of the spiritual dimensions of man, it has to stay conscious and connected to its Creator, and as for that reason, in Islam man has to stay away from intoxicants, drugs and major sins. In an ideal situation, the act of righteousness like prayers, meditation and Qur'anic recitation will guide the thinking man to his ultimate aim in life (Langgulung, 1983; Ansari, 1992).

\section{The Spiritual Mind}

From the Islamic perspective, the human mind is linked to the heart/soul in an intricate way that could be hardly explained by modern science long ago. But from the mystical perspective, it has been well explained by religious masters of different faith groups based on their worldviews. The vast majority of them emphasized that there is a synchronized functioning of the heart and the mind of an individual. It is only very recently, modern science and scientists have come around to acknowledge the relationship between the heart and mind with the new trend in understanding human intelligence. Studies in the area of human intelligence have acknowledged that intelligence is a multidimensional and diverse one (Hamid, 1980). Like creativity, the human intelligence is quite broad. In the beginning the human intelligence is only measured in terms of PO (Physical Quotient) and IQ (Intelligence Quotient). The EO (Emotional Quotient) and SO (Spiritual Quotient) are the later developments that came by in the West. This new way of looking at intelligence in the 
West has now become a trend in education and psychology. A spillover of such an understanding on intelligence from the West has now gone to other parts of the globe as well. With this latest development, the masses regardless in the East or West are made to believe that thinking done by the heart is higher in nature compared to all other intelligence like; PQ, IQ and EQ. The shift towards SO in the West came as a response due to the ever increasing cases of suicide and other mental health issues. It is their belief; with the introduction of SO they will be able to find an amicable solution to resolve the many psychopathological problems found in the Western society. At this juncture of the study, the researchers feel that it is of vital importance to explain that modern spirituality from the Western secular perspective is very different from the one taught by Islam and other Eastern religions and philosophies. In their new definition on spirituality from the secular concept, aspects like God, revelation, angels, prophets, hereafter and eschatology are all together missing. To them, spirituality is an achievement of an individual living in a heightened consciousness in the presence of nature and fellow human beings. In other word, spiritually is a state of living with the sense of humanness in the togetherness with nature and humanity (Badri, 1979; 2002; Ryan, 2011).

Conversely, in Islam, the mind, soul and heart must be linked to God. These entities are considered the spiritual mediums through which man receives guidance in the form of inspiration, intuition, instinctual feeling, etc. from his Creator. The spiritual mind is one that is God-centered. The human spirit as a life giving entity is a divine spark from God to man. As such, man has to abide the laws given by God. As the recipient of God's spirit, man has to fulfill his designated role as the Khalifah of Allah (God's vicegerence) on this earth. Being the honoured creation of God, the ideal thing for him to do will be to stay connected to God at all times. Besides that, the spiritual mind is also expected not only to bind a good relationship with God but also with fellow human beings (Muslims and non-Muslims) and nature (flora and fauna). Though the natural and human sciences are essential for the human survival, but they won't be able to explain life as a whole comprehensively. Perhaps science will only explain to us on how humanity arrived here on this planet, while religion will explain the questions on why we are put here and what is expected of us in this life. At times, science can fail to answer such philosophical questions. As such, we need greater wisdom and guidance from God to explain to us about life and the reason as to why we have been placed on this planet (Amjad, 1992).

\section{The Philosophical Mind}

The development of philosophy in the Muslim empires came after the era of Khulafah al-Rashideen (633-661). Muslim scholars were attracted to the philosophical thoughts and ideas as and when they came in contact with earlier civilizations like that of the Greek, Persian and Indian. The growth of philosophy as a vital and glamorous discipline happened during the Abbasid period (750-1258) in Baghdad. Concurrent to the development in Baghdad, a similar situation was also taking place in Muslim Spain (711-1492), a dynasty established by one of the runaway rulers of the Umayyad caliphate. Later, a similar pattern 
Mohd Abbas Abdul Razak et al.

was taking place in Damascus and Cairo. All this learning centers were actively participating in the translation of ancient manuscripts from other languages into Arabic.

Famous among the Muslim philosophers during the peak of the Islamic civilization were Al-Kindi (801-873), Al-Farabi (872-950) and Ibn Sina (980-1037). Al-Ghazali (1058-1111) who came later was unique in the Muslim world as he has been classified as a Muslim theologian, Sufi and philosopher. In the beginning, Muslim scholars were elated with the ideas of Socrates (470-399BC), Plato (428-347BC), Aristotle (384-322BC) and other Greek philosophers without realizing that besides the beautiful ideas present in the Greek philosophy, there were also some pitfalls in them which the Muslims should avoid. AlGhazali in realizing the dangers of translating without filter as to what can be taken and not from the philosophies of others, wrote the Tahafut al-falasiha (The Incoherence of the Philosophers) as a way to caution Muslim philosophers of their mistakes in over-glorifying philosophy without scrutinizing the ideas taken from the Greek, Persian and Indian philosophies without looking at them from the Islamic perspective. In this monumental work of his, Al-Ghazali highlighted 20 areas where his predecessors had gone wrong (Sheikh, 1974).

Philosophy went into a deep slumber ever since the coming of Al-Ghazali's Tahafut alfalasiha (1963). Later, it came back from its hibernation with the appearance of Ibn Rushd who happened to be the last of the Muslim philosophers of the Muslim golden era. Ibn Rushd who was born in Cordoba, Spain, wrote the Tahafut al-Tahafut (The Incoherence of the Incoherence) as a criticism against Al-Ghazali for causing the death of philosophy in the Muslim World. In defense of philosophy, Ibn Rushd explained that the Qur'an encourages the act of thinking; critically, creatively and analytically, plus observation and contemplation of God's mighty work in the universe, etc. To him, such activities are characterized as philosophical ways of thinking about one's existence in the whole spectrum of God's creation. A student of philosophy will be well aware that philosophy per se is a field of knowledge that is interested in the meaning, truth and wisdom on any particular subject that comes under its purview. Moreover, he stressed that there are many verses of the Qur'an which are philosophical in nature. As such, he felt that it was wrong of Al-Ghazali to criticize philosophy and the philosophers. It is pretty much natural for one who is trained in the philosophical way of thinking to have a pattern of thinking that includes syllogism, thesis, anti-thesis and synthesis. Furthermore, the philosophical mind is capable of looking at an issue from different perspectives, coming up with an in-depth analysis and perhaps able to debate on a given topic much more persuasively than of a simple mind (Sheikh, 1974).

\section{The Scientific Mind}

There was a time in the history of the European nations, whereby science was seen as a thread to revelation and religion. The theories discovered by scientists did not go well with the people holding power in religious establishments. Just for the reason, when the findings of science contradicted scriptures, verdicts were passed against scientists, inventors and innovators. Many of them were either jailed or tortured to death. In contrast to that, in the 
Muslim world the scenario was altogether different from what was happening in Europe. Right from the very beginning of the first revelation to the era of Muslim globalization and to the present day, science was never seen as rivalry to religion. In fact, science helps in many ways to elucidate theories found in the Qur'an more elaborately with the coming of sophisticated scientific tools. In Islam, except for the atheistic and secular concepts of modern science, all other aspects of science are well accepted and celebrated in Islam (Nasr, 1994).

Though the Qur'an was sent to guide mankind to good character and righteousness, nevertheless it also contains scientific facts and theories. A keen researcher of the Qur'an will be surprised to find information on fetal development in the mother's womb and other aspects of embryology (Al-Qur'an 23:12-14i 53:45-46; 39:6; 75:37), how the universe was created and other matters on cosmology (Al-Qur'an 13:2; 15:19; 65:12; 21:30; 41:12), sea currents and oceanography (Al-Qur'an 24:40; 55:19-20; 27:61; 25:53), formation of the mountains, tectonic plates and other issues related to geology (Al-Quran 24:40; 25:53; 27:61,88; 55:19-20), etc. Muhammad Iqbal (1877-1938), Sheikh Muhammad Abduh (18491905) and Jamaluddin al-Afghani (1839-1897), Malik Bennabi (1905-1973), Said Nursi (18771960) and many others called Muslims to embark on the bandwagon of science and to perform scientific investigations. According to these scholars, such an act will be a soul enriching process when one discovers through scientific investigations on Allah's mighty hand behind the making of the universe and the secrets found in the natural world. At the personal level, Iqbal metaphorically praises the scientists for their observation on nature and universe at large, as a sort of mystic seekers trying to get close to the Creator by probing the wonders of the natural world. This act of the scientists he calls as a form of ibadah (worship) in Islam. Likewise, Iqbal also calls the Muslim Ummah to improve their lives by utilizing science and technology to extract the bounties of Allah in the natural world and use them for their spiritual development. A precise explanation of what lqbal says is that, Muslims should extract the natural resources from the belly of earth and convert them into wealth and use it to improve the condition of the Ummah. Simply put, a mind that is interested in science and its calculations and discoveries will most probably appreciate not only the spectacular beauty in the natural world, but also the precision orbiting of the planets and the presence of God behind all created matters, including man (Iqbal, 1996).

\section{The Benefits of Developing the Traditional Mind}

The human mind is an amazing, beautiful and powerful creation of God Almighty. According to most psychologists, under normal circumstances man uses way below the mind's full potential. At times, it has the tendency to drive human beings to perform extra ordinary acts when their lives are threatened or in search of a solution. Besides that, psychologists also believe if the mind is fed with proper knowledge and training, it can overcome many obstacles. For the mind, reading and training provided in the areas of critical and creative thinking can help an individual to overcome many of his insurmountable problems as an individual as well as a nation. In the Qur'an, the Muslims are encouraged to 
Mohd Abbas Abdul Razak et al.

think, ponder, contemplate, etc. What comes below here are some of the benefits of going back to the qualities of the traditional mindset (Badi, 2004).

Living in the new millennium, Muslim communities inhabiting in many parts of the world are confronted with enormous amount of modern day new issues. At times, many of such issues challenge the very foundation of their Islamic faith and survival as a religious community. Besides that, they are ostracized and called by obscure names; such a terrorist, fundamentalist, backward and uncivilized people. The actions of others against Muslims give the impression as though the whole world is crying for peace, while the Muslims are the ones who desire for war and chaos. Under the present world condition which is steep in Islamophobia, racism and prejudice, the researchers are of the conviction that by reviving the qualities of the traditional mind, Muslims would be in a better position than before to avert or counter those false accusations and assumptions in an intellectual manner by good rhetoric, sound reasoning using logic and philosophy. At the moment, this is not happening because in many instances, Muslims respond negatively or in a wrong way to global news reports that disparage their religion and their Prophet. This sort of attack on the Muslims via essays and caricatures that appear on the print and internet media provokes Muslims. For very long, the Muslims have responded with emotional sloganeering against the West. In some situations, demonstrations organized by Muslims communities have created tension between them and the law enforcement authorities in many Western countries (AbuSulayman, 1993; Al-Roubaie, 2002).

With the new approach in the way of thinking and handling the day-to-day issues, many Muslim countries would be able to bring the much needed development and progress for the masses. A progressive Muslim country should be able to strike a balance in the many sectors of its national development. Among the developments that must be given due attention will in the areas of infrastructure, science, technology, moral and spiritual developments, citizenship, eradication of poverty and illiteracy. Apart from that, this mindset should enable the Muslim community to take a forward march in the preservation and conservation of nature (Ould Bah, 1998). When a Muslim nation is developed in the aforementioned areas, it can reduce its dependency on others in terms of its science and technology, particularly the advanced nations in the West. In a way, the reviving of the traditional mind should be seen as an actualization or materialization of the true teachings of the Qur'an. The holy book of the Muslims not all together focuses on the hereafter, but also emphasizes the importance of this earthly life and the role of man in administrating, preserving and conserving this world (Al-Qur'an 2:30; 33:35; 28:77) (AbuSulayman, 1993). lqbal (1996) highlights this fact by stating that though the Qur'an was revealed during the classical period of the Muslims, its message and spirit is anti-classical. Meaning it is meant for all times and places. As a practical guide book and a manual for life, one can find wisdom and a way of conduct in all situations of the human life.

\section{How to Cultivate the Traditional Mind}

Since education starts from home, the effort to cultivate the traditional mind in the Muslim world should start from the family. All Muslim families, regardless where they live 
should encourage their children to get interested in science and scientific discoveries. While interacting with their children, Muslima parents should not only talk about Islamic subjects on faith and practices, but also on scientific facts mentioned in the Qur'an and how to appreciate Allah's beauty manifested in the natural world and the universe at large. From the time children learn how to speak, parents should encourage their children to ask questions like on what, when, why, why not, how, etc. in matters related to education, religion and science. During their children's process and progress of growing up, parents have to be tolerant in entertaining their children's inquisitive minds. Besides that, parents should felicitate their children's learning by making books on science, religion, ethics, etc. accessible to them. Children's reading habits cultivated during their childhood period can go a long way in making them as avid readers in the areas of science, philosophy, creative thinking, history, etc. in the future. Moreover, reading increases their power of imagination, critical and creative thinking skills, and general knowledge of their immediate environment and the affairs of the modern world. The last thing that can be said on childhood education is that, modern day Muslim parents need to change their style of parenting from the old school of thought to the new in line with their children's generation so long it is not against the Islamic norms and values. This is necessary for the reason that today's children are getting information and knowledge in abundance from many outlets. As such, parents not only make knowledge available in their lives but also monitor on what they read, how they think and respond to what they have come to know.

Meanwhile, governments in the Muslim World should introduce an integrated curriculum in the national school system, particularly at the primary and secondary levels. The integrated curriculum should incorporate religious study, science, art and craft, music, mathematics, and other human sciences. Teaching a single subject be it religion, science or mathematics in isolation is not an ideal thing to do. Over emphasis on a particular subject at the expanse of neglecting other sciences in the educational endeavor of the child most likely can cause an imbalance in the personality of the learner. Educationists and psychologists believe that every subject learned in school contribute in some ways to the overall personality development of an individual. An integrated curriculum should not only be introduced at the national school but also at the independent or private Islamic schools. Introducing a balanced and integrated curriculum should not be seen a foreign idea to Islam for the reason the Qur'an speaks of a good life in this world and the hereafter (Al-Qur'an $2: 201 ; 28: 77)$.

With regard to education at the tertiary level, Muslim governments around the world should introduce their students to an integrated curriculum which includes the revealed, natural and human sciences. Students who are enrolled in the faculties of human and natural sciences at the university level should be offered elective subjects like Islamic Worldview, basic philosophy, basic psychology, Islamic Ethics, Islamic Civilization, etc. As the same time, students enrolled at the faculty of Islamic Sciences should be encouraged to take a few introductory courses in philosophy, psychology, creative and critical thinking, etc. By introducing the integrated curriculum at the university level, the Muslim World would be able to produce young Muslim graduates who are versatile in many areas of knowledge. Not 
Mohd Abbas Abdul Razak et al.

only that, they will be more marketable according to the demands of the modern world, but would be able to grapple with issues related to spirituality, morality, good governance, etc. It is also expected that an integrated curriculum would enable Muslim countries to produce citizens who are not only highly professionals but also integrated in their personality, otherwise known as a balanced-personality. More importantly, they will be able to serve better towards their family, society, religion, country and humanity at large.

In summation to the foregoing debate on education, parents, teachers and the governments in the Muslim World should look at knowledge and education in a broader perspective rather then what has been observed narrowly in many parts of the world. Education should not be confined to the four walls of the classroom only. From the Islamic perspective, anything can be a learning process under the sun. Taking students on a field trip and introducing them to the beauty of flora and fauna or taking them to the beach and explaining about marine life all can be an educational venture for the students. The last thing can be said on education is that, education is not only for the mind, but it is also for the spirit/soul, heart and self of an individual.

\section{E. Conclusion}

This research has shed some light on the importance of reviving the qualities of the traditional Muslim mind of the past. In a way, this research has also highlighted the fact that much of the problems in the Muslim world during the post-colonial era till now are mainly related to our orientation of thinking. In realizing the pattern of thinking among the Muslim masses today is fragmented; either too much on religion or science or philosophy, etc. the researchers analyzed the mindset of the past Muslim scholars who were great thinkers, philosophers, mathematicians and scientists. In the course of analyzing, they researchers have found out that in the bygone centuries, Muslims and their empires were dynamic as a result of their pattern of thinking; which is one blended in spirituality, science and philosophy. The researchers feel that, if the same pattern is observed at present there is a great possibility modern day Muslims would be able resolve many of the problem faced by them. At the same time, they can stand tall with the rest of the world. With regard to the Islamic civilization, reviving the qualities of the traditional Muslim mind gives a glimmer of hope to the Ummah in its aspiration of reclaiming the past glory and fame.

\section{BIBLIOGRAPHY}

Abdul Karim, Abdul Rahim. (1991). War-dance of the superpowers: the US-led war on Iraq. Thaj Publishing Division.

Abdul Razak, Mohd Abbas. (2015). Reclaiming fame and glory of the Muslim world. New Straits Times, Saturday, 1st August, p.17.

Abdul Razak, Mohd Abbas. Rahath, Yousef. Abdul Razak, Abdul Latif. (2016). Less politicking and more thinking is needed to revive the Islamic civilization. A paper 
presented at the 2nd Kuala Lumpur International Islamic Studies \& Civilizations Conference, 8-9th Oct., 2016, Hotel Putra, Kuala Lumpur, Malaysia.

Abu Sulayman, Abdul Hamid A. (1993). Crisis in the Muslim mind, Virginia International Institute of Islamic Thought.

Al-Attas, Syed Muhammad Naquib. (1978). Islam and secularism. Muslim Youth Movement of Malaysia.

Al-Attas, Syed Muhammad Naquib. (1990). The nature of man and the psychology of the human soul. International Institute of Islamic Thought and Civilization, International Islamic University Malaysia.

Al-Attas, Syed Muhammad Naquib. (1991). The concept of education in Islam. Kuala Lumpur: International Institute of Islamic Thought and Civilization, International Islamic University Malaysia.

Al-Ghazali, Abu Hamid. (1963). Tahāfut al-Falāsifah [Incoherence of the philosophers]. (Sabil Ahmad Kamali, Trans.), Pakistan Philosophical Congress.

Al-Roubaie, Amer (2002), Globalization and the Muslim world, Shah Alam: Malita Jaya. Ansari, Zafar Afaq (ed). (1992). Qur'anic concepts of human psyche (pp.1-14). Islamabad: International Institute of Islamic Thought (Pakistan).

Amjad, Naumana. (1992). Psyche in Islamic Gnostic and philosophical traditions. In Ansari, Zafar Afaq (ed.), Qur'anic concepts of human psyche (pp.39-56). International Institute of Islamic Thought (Pakistan).

Badi, Jamal. (2004). Creative thinking: an Islamic perspective. International Islamic University Malaysia, Research Centre.

Badri, Malik Babikar. (1979). The dilemma of Muslim psychologists. MWH London Publishers. Badri, Malik Babikar. (2000). Contemplation: An Islamic psychospiritual study. Medeena Books.

Bakar, Osman. (1991). The history and philosophy of the Islamic science. Islamic Texts Society.

Bakar, Osman. (2008). Tawhid and Science. Arah Pendidikan.

Busha, Charles \& Harter, Stephen, P. (1980). Research methods in librarianship: Techniques and interpretations. Academic Press.

Denzin, Norman, K. \& Lincoln, Yvonna, S. (eds). (2008) Strategies of qualitative inquiry (3 ${ }^{\text {rd }}$. ed.), SAGE Publications.

Fakhry, Majid. (1983). A history of Islamic philosophy, LONGMAN London

Freud, Sigmund. (1950). Freud: Dictionary of psychoanalysis. Nandor Fodor \& Frank Gaynor (eds), Philosophical Library.

Freud, Sigmund. (1962). Five lectures on psycho-analysis. PENGUIN Books.

Freud, Sigmund \& Gay, Peter. (1989). The ego and the id. W.W. Norton \& Company Inc.

Hamid, Abdul-Fattah Rashid. (1980). Self knowledge and spiritual yearning. American Trust Publication.

Hassan, M.Kamal. (2011). Voice of Islamic moderation from the Malay world. Perak: Emerging Markets Innovative Research. 
Mohd Abbas Abdul Razak et al.

Hiro, Dilip. (1989). Paladin movements and ideas: Islamic fundamentalism. Paladin Grafton Books.

Hosein, Imran N. (2011). Jerusalem in the Qur'an. San Fernando: Masjid Jami'ah, City of San Fernando.

Iqbal, Muhammad. (1996). The reconstruction of religious thought in Islam, Lahore Institute of Islamic Culture.

Khader, Bichara. (2015). "Muslims in Europe: The Construction of a "Problem"." In The Search for Europe. Contrasting Approaches. BBVA

Langgulung, Hasan. (1983). Teori-teori kesihatan mental: Perbandingan psikologi moden dan pakar-pakar pendidikan Islam. Pustaka Huda.

Maslow, Abraham. (1968). Toward a psychology of being. (2 ${ }^{\text {nd }}$ edn.). D. Van Nostrand.

Nachimias, David. \& Nachimias, Chava (eds.). (1982). Research methods in the social sciences. ( $2^{\text {nd }}$ edn.). Edward Arnold.

Nasr, Seyyed Hossein. (1994). A young Muslim's guide to the modern world. Muslim Youth Movement of Malaysia.

Ould Bah, Mohamed El-Mokhtar. (1998). Islamic Education between tradition and modernity, Publications of the Islamic Educational, Scientific and Cultural Organization-ISESCO.

Ryan. Jim. (2011). The spiritual mind: a journey into awareness. Brahman Kumaris Information Services Ltd.

Sharma, Ramdutt. (1988). Research Methods in Social Sciences. National Book Organisation. Sheikh, M Saeed. (1974). Studies in Muslim philosophy. SH. Muhammad Ashraf.

Verma, R.K. \& Verma, Gopal. (1989). Research Methodology. Commonwealth Publishers. Watson, John Broadus. (1928). The ways of behaviorism. Harper \& Brothers Publishing.

Watson, John Broadus. (1970). Behaviorism. W.W. Norton. 